\title{
IS DISEASE CULTURAL? ANALYZING THE DIFFERENTIAL DEMOGRAPHIC IMPACT OF COVID-19 IN INDIA AND SPAIN
}

\author{
Niamat Anand \\ The Shri Ram School, Moulsari \\ DOI: 10.46609/IJSSER.2020.v05i07.026 URL: https://doi.org/10.46609/IJSSER.2020.v05i07.026
}

\begin{abstract}
The COVID-19 pandemic has been tackled most directly through the lens of the capitalist economy, coupled with epidemiological study. However, despite scientific data and progress being the driver of the trajectory of the pandemic, each country's response has been different and most often dictated by ideological leanings of the ruling government, and the culture particular to the country. The broad similarity is economic devastation and lack of measures to effectively assist the poorest and vulnerable, but culture is able to show the drivers behind each government's varied response. This paper will shed light on the cultural and demographic influences that have shaped the responses to the pandemic, with a particular focus on India and Spain. In conducting this comparative analysis between India and Spain, the paper aims to expand the scope of the discussion about the ongoing pandemic, from purely economic terms to one that is more socially oriented but founded on scientific inquiry and data collection.
\end{abstract}

Keywords: Disease, Culture, Pandemic, Economy, COVID-19

\section{INTRODUCTION}

The COVID-19 pandemic that has brought the world to a standstill has exposed several flaws in the economic and social systems in different countries, with disproportionate effects on the poor, inadequate political responses and blame being placed on various sources for the spread of the virus. From a cultural standpoint, it is crucial to recognize that the pandemic has affected different sections of the population on the basis of class, religion, geography, age, and other factors. The disparity in how some classes of the population are affected vis-à-vis others has exposed the levels of privilege and hegemonic nature of the elite classes, as well as varying priorities of national governments who have in most parts of the world struggled to create a coherent and strategic response. 


\section{International Journal of Social Science and Economic Research}

ISSN: $2455-8834$

Volume: 05, Issue: 07 "July 2020"

Experts in the field of epidemiology across the world have been researching the incidence, distribution, and possible control of the coronavirus, issuing guidelines for the public and trying to collect crucial data that could predict the trajectory of the disease and inform government policy on the most effective ways to curb the spread and flatten the curve, buying time for health facilities to be able to bear the load. However, what has been shown in the cases of several countries is that epidemiology has been stalled, interfered with or influenced by political decisions which are based on biases rather than science (The Print, 2020). For example, the USA had a severely delayed response to even acknowledging the pandemic, with the president referring to it as a 'hoax' created by Democrats to gain political leverage (Milman, 2020). Countries like Hong Kong and Taiwan quickly began to increase testing and impose public health measures which has led to their fatality rates being much lower (NYT Live Briefings, 2020).

A country's response, so far, appears to have among the largest impact on the severity of an outbreak and the subsequent number of deaths, as demonstrated by South Korea's apparent success (which was also achieved without broadly shuttering daily life) (Courage, 2020). In this light, this paper will discuss the demographic impacts of the pandemic with a particular focus on India, and Spain. The paper will undertake a comparative analysis of the cultures and politics of the two countries, with respect to population demographics, political or religious biases, and the resultant consequences of the countries' responses being informed by these cultural factors, rather than epidemiological research. The two countries - Spain and India - have been specifically chosen owing to specific similarities in their histories and contemporary socio political environments, including the presence of political infighting, fragmented cultures, the existence of contentious politics, and polarized parties at the central as well as state-government levels, which has directly impacted the ways in which COVID-19 has been perceived, assessed, treated, responded to, and understood by the respective governments. The paper, thus, considers the differential spread in COVID-19 in critical consideration of these factors, contrasting the South Asian and European perspectives to the pandemic.

\section{BACKGROUND}

In India, the first case of COVID-19 was traced in early February of 2020. In the first week of February, the Integrated Disease Surveillance Programme, a government initiative under the health ministry's National Centre for Disease Control, recorded in its weekly report that India had reported its first three positive cases of COVID-19 (Krishnan, 2020). In Spain, 31 January 2020, when a German tourist tested positive for SARS-CoV-2 in La Gomera, Canary Islands (Manuel, 2020). Post-hoc genetic analysis has shown that at least 15 strains of the virus had been imported, and community transmission began by mid-February (Manuel, 2020). India has 


\section{International Journal of Social Science and Economic Research}

ISSN: $2455-8834$

Volume: 05, Issue: 07 "July 2020"

consistently maintained that community transmission has not begun in the country, and has been successfully averted, unlike Spain (Krishnan, 2020).

India imposed a nationwide lockdown in the beginning of April, which is set to possibly end by the end of May, with some services resuming. The death rates of Spain have been much higher than that of India. Spain has been one of the worst-hit countries with more than 28,000 deaths, while India has had 3,728 deaths (Worldometers, 2020). The large disparity between the number of deaths in these two countries despite India's higher population and being a relatively poorer country, is being investigated by epidemiologists. Spain's failure to response quickly has been attributed to lack of coordination, failure to source essential equipment, ventilators, protective clothing for doctors and coronavirus tests, and no timely imposition of emergency lockdowns (Tremlett, 2020). India imposed a very strict lockdown with criminal consequences, which may have been a reason for the containment of the virus, although several experts point out that the lack of testing may mean that there are far more deaths than reported (Krishnan, 2020).

One factor is age, and it has been observed in general that countries with younger populations have experienced a lower case fatality rate (CFR) (Courage, 2020). For this coronavirus, SARSCoV-2, older individuals are far more likely to become critically ill or die from the disease (Courage, 2020). India in general has a much larger proportion of younger people than Spain, which could have contributed to lesser fatalities (The Print, 2020). However, it is important to not only place focus on the number of deaths but the social and economic impacts of the restrictions placed on the public, and the institutional infrastructure. There is a large proportion of the population in both India and Spain who may have not been affected with the disease but are suffering a ruinous economic impact and poverty due to the lack of adequate supporting infrastructure and biases of the government. This will be examined further in the following section.

\section{DISCUSSION}

Political infighting has proven to be a reason for the lack of coordination and public understanding of the crisis in both countries, especially Spain. Spain is a federalist country, where autonomous regions hold power over a range of policy areas including healthcare (Giugliano, 2020; Tremlett, 2020). Prime Minister Sanchez eventually claimed emergency powers for his government, but only after a string of regional politicians had resisted. The opposing right-wing Popular Party behaved opportunistically (Giugliano, 2020; Tremlett, 2020). It attacked Sanchez after his decision to close down all non-essential activities, seemingly changing course from earlier calls for a tougher lockdown - only to change tack and support the stricter measures (Giugliano, 2020). Meanwhile, Pablo Iglesias, the leader of the left-wing Podemos party, which runs the country in a fragile minority coalition with the Socialists, has 


\section{International Journal of Social Science and Economic Research}

ISSN: $2455-8834$

Volume: 05, Issue: 07 "July 2020"

sought to exploit the emergency to push his agenda of sweeping nationalizations (Giugliano, 2020). This further put a strain on their already fragile healthcare system, which has been radically downsized by a decade of austerity due to the 2008 financial crisis (Tremlett, 2020).

Similarly, in India, the right wing nationalist party of Prime Minister Modi has stirred up religious bias and sought to blame most of the spread on the activities of the Muslim Tablighi Jamaat, despite the fact that the spread was also caused by several gatherings of Hindus in religious places (Rai, 2020). One can understand the initial temptation that led to this development. The unfortunate and irresponsible Tablighi Jamaat event at Nizamuddin offered a heaven-sent opportunity to adapt the virus epidemic into a familiar form of sectarian, communal politics - the old "Hindu-Muslim" trick (Rai, 2020). Suddenly, being infected with the virus was not a misfortune, but a deliberate, terrorist act. Once infected, one became infectious - and so potentially harmful to others, practically a terrorist, a message widely spread by pro-government media (Rai, 2020).

The similarity in both countries is the respective governments seeking to further their political agenda through the virus lockdown policies. This has effectively distracted the elites and middle classes who could emerge through restrictions relatively unscathed, from the plight of the poor and vulnerable (Rai, 2020). In both countries, the poor have suffered disproportionately. In Spain's Catalan region, the coronavirus mortality rate among some of the poorest Catalans is five times higher than among the wealthiest residents of the Spanish region, a study showed, in the latest evidence of how COVID-19 hits the needy hardest (Faus, 2020; Tremlett, 2020). The data echoes similar studies in other Western nations that have shown that poorer citizens, as well as non-white ethnic groups, have been hit the hardest (Faus, 2020).

In India, the huge number of transient migrant workers (there are no official figures, but the most often cited number is 100 million) have struggled to survive, and have been driven to starvation and walking arduously long distances to reach their homes in rural areas (Rai, 2020). Whereas governments in Britain, Spain, and Germany have offered stimulus plans of up to 20 percent of GDP, India's amounts to less than 1 percent of its GDP (Krishnan, 2020). It provides no help for day laborers or other workers in similar unorganized sectors. It contains no measures for migrant workers (Krishnan, 2020). The actual amounts of support-five kilograms of rice or wheat, and one kilogram of legumes, per person for the next three months, coupled with cash transfers, in some cases of 500 rupees, or \$7, a month, has been heavily criticized (Krishnan, 2020). Since the restrictions came into force, buses and trains have stopped ferrying passengers across the country, leaving them to walk, often for days, with their families back to their towns and village (Krishnan, 2020; Rai, 2020). 


\section{International Journal of Social Science and Economic Research}

ISSN: $2455-8834$

Volume: 05, Issue: 07 "July 2020"

Similarly, in Spain, even despite a left wing Socialist government, the pandemic has taken a disproportionate toll on the poor, the elderly, the marginalised and those working in low-paid but vital jobs (Faus, 2020). Spain's Socialist-led coalition government has announced a four-phase transition towards some kind of return to normality, and launched what it calls "the greatest mobilisation of resources in Spain's entire democratic history" to help the country weather the pandemic (Jones, 2020). However, this has failed to revive the economy to the extent that is required. While it may be an egalitarian blight, Covid-19 is already being felt most keenly by the most marginalised of the marginalised - including sex workers and victims of trafficking (Jones, 2020). Prostitution was decriminalised in Spain in 1995 and the sector is now thought to employ about 300,000 people (Jones, 2020). The government announced sex workers and victims of trafficking and sexual exploitation will be offered support, emergency accommodation and access to the new benefit to be known as the minimum vital income while the crisis lasts (Jones, 2020). However, activists have criticized this measure as being inadequate.

Therefore, while there are significant differences in the ideological leanings of the governments in India and Spain, the similarities lie in the lack of testing, and political objectives of the government being given precedence over epidemiological considerations. There are vast differences in culture as well, be it the religious bias in India, or the acceptance of sex work in Spain. However, the economic underpinnings of the pandemic largely affecting the poor, vulnerable and marginalized remain common, as well as a lack of government action on testing, data collection, and improvement of health services (Courage, 2020).

\section{CONCLUSION}

While the effects of the disease on different sections of the population may be cultural, a larger similarity can be found not only between India and Spain but across all countries in terms of a delayed response and adverse economic impact. Scientists have been largely assessing the situation by looking at the median age of the population, but it is clear from the impact it has had that cultural, economic, political and social factors are equally if not more important indicators for how countries will be impacted. In many ways, this global pandemic is laying bare what really matters to different nations, and in the process, revealing a lot about a country's character (Dhian Ho, 2020).

One of the big questions that remains to be answered is how the overlapping factors of a country's age demographics and its health care resources impact the fatality rate (Courage, 2020). Going off of median age or the proportion of the population 65 or older may or may not end up being the next strongest predictor (Courage, 2020). 
International Journal of Social Science and Economic Research

ISSN: $2455-8834$

Volume: 05, Issue: 07 "July 2020"

As the pandemic spreads around the world it is increasingly clear that culture matters when it comes to the coronavirus (Dhian Ho, 2020). It is a question not only of an individual or collective perspective, but also of a long-term versus a short-term orientation. (Dhian Ho, 2020) We can identify various dimensions when assessing political viewpoints: cultural, left-right and unilateral-multilateral dimensions (Dhian Ho, 2020). The cultural dimension recognises the huge political importance of the collective orientation (communitarians) or individual orientation (individualists) mentioned previously (Dhian Ho, 2020). Although all leaders call for solidarity at times of major crisis, there are clear differences between the political reactions of countries depending on the governments agenda- be it the Hindu nationalist agenda in India, or the socialist agenda in Spain (Dhian Ho, 2020).

With hindsight and thorough analysis, we will eventually be able to more carefully plot out steps and missteps and what combinations of factors from these experiments came to mean for different populations (Courage, 2020). With that knowledge, governments must be able to better head off the next pandemic threat, which could be even more virulent (Courage, 2020), tackling problems with a scientific orientation rather than a political one.

\section{REFERENCES}

Courage, KH, (22 April 2020), 'The stark differences in countries' coronavirus death rates, explained’, Vox, https://www.vox.com/2020/4/1/21203198/coronavirus-deaths-us-italychina-south-korea

Dhian Ho, M, (21 March 2020), 'The culture and politics of the coronavirus', Clingendael Magazine, https://www.clingendael.org/publication/culture-and-politics-coronavirus

Faus, J, (22 May 2020), 'Virus Deaths Five Times Higher Among Poor in Spanish Region', The New York Times, https://www.nytimes.com/reuters/2020/05/22/world/europe/22reutershealth-coronavirus-spain-study.html?auth=login-google

Gigugliano, F, (6 April 2020), 'How Spain tragically bungled its response to coronavirus', The Print,_ https://theprint.in/opinion/how-spain-tragically-bungled-its-response-tocoronavirus/396335/

Jones, S, (4 May 2020), 'The situation is critical': coronavirus crisis agony of Spain's poor', The Guardian,_https://www.theguardian.com/world/2020/may/04/the-situation-is-criticalcoronavirus-crisis-agony-of-spains-poor

Krishnan, V, (12 May 2020), 'Epidemiologists say India's centre for disease control withheld COVID-19 data since pandemic began', The Caravan, 
International Journal of Social Science and Economic Research

ISSN: 2455-8834

Volume: 05, Issue: 07 "July 2020"

https://caravanmagazine.in/health/epidemiologists-say-india-centre-disease-controlwithheld-covid-19-data-since-pandemic-began

Krishnan, V, (27 March 2020), 'The Callousness of India's COVID-19 Response', The Atlantic, https://www.theatlantic.com/international/archive/2020/03/india-coronavirus-covid19narendra-modi/608896/

Manuel, A, (23 April 2020), 'Genetic Analysis suggests that coronavirus was already circulating in Spain in mid february', El Pais, https://elpais.com/ciencia/2020-04-22/el-analisisgenetico-sugiere-que-el-coronavirus-ya-circulaba-por-espana-a-mediados-defebrero.html

Milman, O, (31 March 2020), 'Seven of Donald Trump's most misleading coronavirus claims', The Guardian, https://www.theguardian.com/us-news/2020/mar/28/trump-coronavirusmisleading-claims

New York Times Live Briefing, (11 April 2020), 'India to Extend Lockdown Against Coronavirus, While Spain Eases Work Rules', https://www.nytimes.com/2020/04/11/world/coronavirus-news.html?auth=login-google

Rai, A, (10 May 2020), 'How India is outsourcing the COVID-19 pandemic to its poor', The Caravan, https://caravanmagazine.in/health/india-outsourcing-covid-pandemic-to-poor

The Print, (22 May 2020), 'CDC new Covid guidelines: Was lockdown necessary or did epidemiologists get it wrong?', https://theprint.in/talk-point/cdc-new-covid-guidelineswas-lockdown-necessary-or-did-epidemiologists-get-it-wrong/427317/

Tremlett, G, (26 March 2020), 'How did Spain get its coronavirus response so wrong?', The Guardian, https://www.theguardian.com/world/2020/mar/26/spain-coronavirus-response$\underline{\text { analysis }}$ 